\title{
Java Language in Dutch Indies Advertisement 1930 - 1939
}

\author{
Thomas Nugroho Aji* \\ History Education Department \\ Faculty of Social Sciences and Law, \\ Universitas Negeri Surabaya, Indonesia \\ thomasnugroho@unesa.ac.id
}

\author{
Arief Sudrajat \\ Sociology Department \\ Faculty of Social Sciences and Law, \\ Universitas Negeri Surabaya, Indonesia \\ ariefsudrajat@unesa.ac.id \\ Artomo \\ History Education Department \\ Faculty of Social Sciences and Law, \\ Universitas Negeri Surabaya, Indonesia \\ artono@unesa.ac.id
}

\author{
Sri Mastuti Purwaningsih \\ History Education Department \\ Faculty of Social Sciences and Law, \\ Universitas Negeri Surabaya, Indonesia \\ nasution@unesa.ac.id
}

\begin{abstract}
The history of advertising in Indonesia especially during the Dutch East Indies around 19301939 was a period of economic development in the Dutch East Indies after the world economic recession. One of the regions that enjoys the economic development is Java. The current Javanese population is the main target of these advertising products so that the Dutch colonialists tried to "influence" and "grip" the Javanese society's consumptive patterns by using Javanese-language advertisements so that they could become the object of market for company products controlled by the Dutch East Indies and parties other foreigners. It is more unique that some advertisements use Javanese for middle to upper class Javanese people so that certain advertisements also describe community stratification. This paper uses the heuristic method in the form of collecting data in the form of both primary and written documents in the form of original or secondary documents in the form of data that has been processed by other authors so that this research is a qualitative descriptive study. besides the historical approach, a sociological approach is also used in analysing advertisements at that time.
\end{abstract}

Keywords: Advertisements, Javanese Society, Javanese Language, Stratification of The Community

\section{INTRODUCTION}

Advertising is a medium for conveying the identity of a product that is packaged in various means such as language, images, films and other aspects such as sound. The 1930s was a period of the Dutch East Indies economic revival after the economic malaise due to the collapse of the global economy and internal factors after the Java War which drained the Dutch state treasury. The factor of the implementation of forced cultivation in the Dutch East Indies also helped the rise of the Dutch economy.

The rise of the Dutch East Indies economy in the 1930s led to the revival of industrialization in the field of goods and services which gave rise to advertising agencies to market several goods and services. One of the main targets of the market for goods and services is Javanese, especially the middle and upper class (although some lower class people are also targeted by these advertisements). To make it easier for the public to accept these advertisements, the use of the Javanese language is quite interesting to observe besides the Malay language which is commonly used in the Dutch East Indies community besides Javanese at that time.

\section{METHOD}

The method used uses two approaches namely descriptive qualitative both in terms of history and anthropology. In the historical approach, heuristic approaches are used to find and collect past sources or information in the form of written sources, including magazines, newspapers and other written sources. These written sources, both published in the past and the current publications that collect data in the form of advertisements during the Indies period. In addition, the anthropological approach used by the Ethnographic Content Analysis (ECA) method is the content analysis activity where there is interaction between the researcher and the document material collected (Altheide, 1987: 65). Content analysis was carried out qualitatively in the form of discourse analysis and textual analysis.

\section{RESUltS AND DISCUSSION}

\subsection{Industrialization of the Colonial Era (1930-1939)}

Industrialization in the Dutch East Indies (Indonesia) began to develop when the era of 20th century colonialism began. In the Dutch East Indies community, especially in Java, the westernization process began after the Dutch private party came to power in the Dutch government and influenced industrialization in the colonies (the Dutch East Indies) and the start of colonial government policies in the establishment of schools in colonies, especially the Dutch East Indies (although much education for nobility named priyayi). With conditions that are able to enjoy education, 
nobles are expected to become a group that changes from traditional feudal thinking to a group that has modern thinking.

Java Island became a Dutch colony that was relatively more advanced and modern compared to other colonies. This is because the center of the Dutch East Indies government was centered on the island of Java and in the history of regional development before the arrival of Western nations, Java has become a relatively advanced civilization compared to other regions or islands.

Besides that, in the island of Java in 1920 there has been a significant population growth compared to other islands. In the 1930 census, the population of the Dutch East Indies reached 60 million with 40.7 million in Java. In addition, in the study of AgusSachari, it was known that there had been a change on the island of Java in the 1930s, namely an indication of a shift from feudal agriculture to modern industrial society, namely the development of industries such as lamp factories, steel and metal factories, factories. soap, milk factory, modern beauty and medicine factory, lemonade and beer factory, agricultural and plantation equipment factory or spare parts factory for other industries such as sugar industry and others. (Sachari: 2007, 58-70).

Javanese priyayis or Javanese royal nobles (the term palace in Javanese) were the main target market for goods and services in the progress of industrialization in the Indies. The nobles were agents of change which would later bring mass consumptive influence to the Javanese people. In the era between 1930 and before the entry of Japan in Indonesia in 1939 there had been a change in the consumer pattern and lifestyle of the Javanese people (Kasuma: 2006, 3-4).

\subsection{Colonial Advertising Era (1930-1939)}

The first advertisement in the Dutch East Indies was published in the newspaper "Bataviasche Nouvelle" which was initiated by the fourth General Governor of the East Indies Trade Union or VOC (Vereenigde Oost Indiche Compagnie), Jan Pieterzoon Coen in August 1744. In Coen's thought, news could be submitted in the form or advertising method. This newspaper also promotes a number of products (Rahzen\&Dahlan: 2007, 2-5).

The advertisement of colonial goods and services products peaked in the 1930s as a sign of the revival of the era of modern industrialization in the Dutch East Indies. One of the printed media that published Javanese advertisements was the "Kadjawen" magazine. This magazine was published by Bale Poestaka Batavia with the editorial address at Bale Poestaka, Batavia- Centrum. The magazine is published twice a week on Tuesdays and Fridays. The contents of this magazine are very diverse, namely from illustrated stories, international and national news, economic news, cultural news and serial stories. In the news that is displayed sometimes some advertisements are inserted in a product or service product. This magazine uses Javanese as the language of instruction (lingua franca). This magazine has the most advertisements or contains the most advertisements compared to other magazines in its era or with other Javanese magazines (Mrazek,2006: 114-115).

In further analysis, the advertisement in "Kedjawen" magazine with the influence of liberalism or the privatization process after the implementation of forced cultivation (culture strategy) and replaced with ethical politics was very significant.

Ethical politics after the implementation of forced planting politics not only gave rise to business groups among the middle and upper middle class indigenous people, ethical politics also led to "consumptive impulses" among other indigenous communities both from the lower classes to the upper class. In the context of communication, advertising does not merely promote the use of certain goods and services, but these advertisements have attempted to provide "influence" so that indigenous Javanese people can recognize and adopt the life values of modern society which at that time referred to European society, especially the Netherlands. In the view of entrepreneurs, the Dutch East Indies community, especially the Javanese people, need and have the right to raise their standard of living by recognizing several products commonly used by Europeans or non-indigenous through the process of modernization.

To facilitate the transformation, some advertisements use the language commonly used by Javanese people at that time, namely the Javanese language. Below are some product advertisements based on their uses.

\subsubsection{Personal hygiene and beauty products}
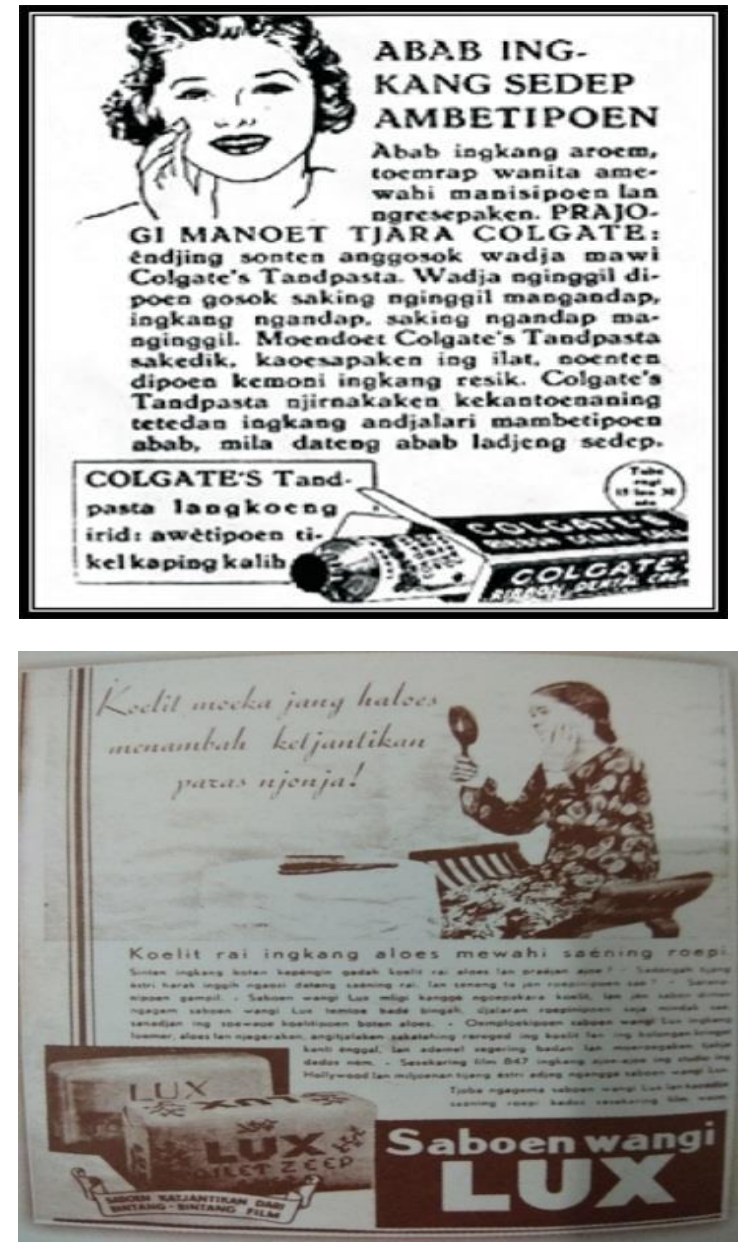

Picture 1. Lux Toothpaste and Soap Advertisement in Javanese with Latin alphabets (Source: Kedjawen Magazine) 


\subsubsection{Food and Beverage Products}
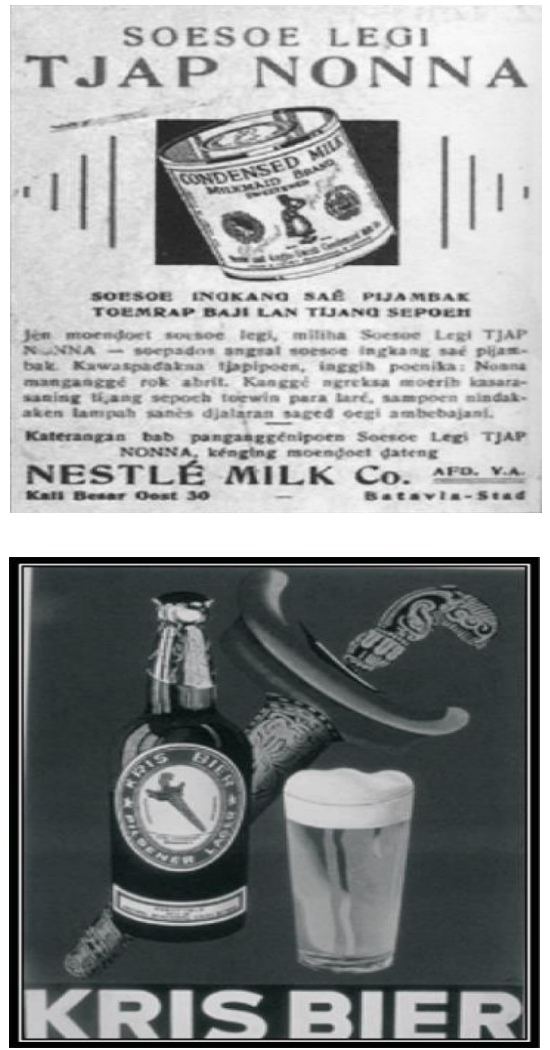

Picture 2. Advertisement of Nestle and Beer Dairy Products in Javanese (Source: Kedjawen Magazine)

\subsubsection{Agricultural Equipment and Fertilizers}
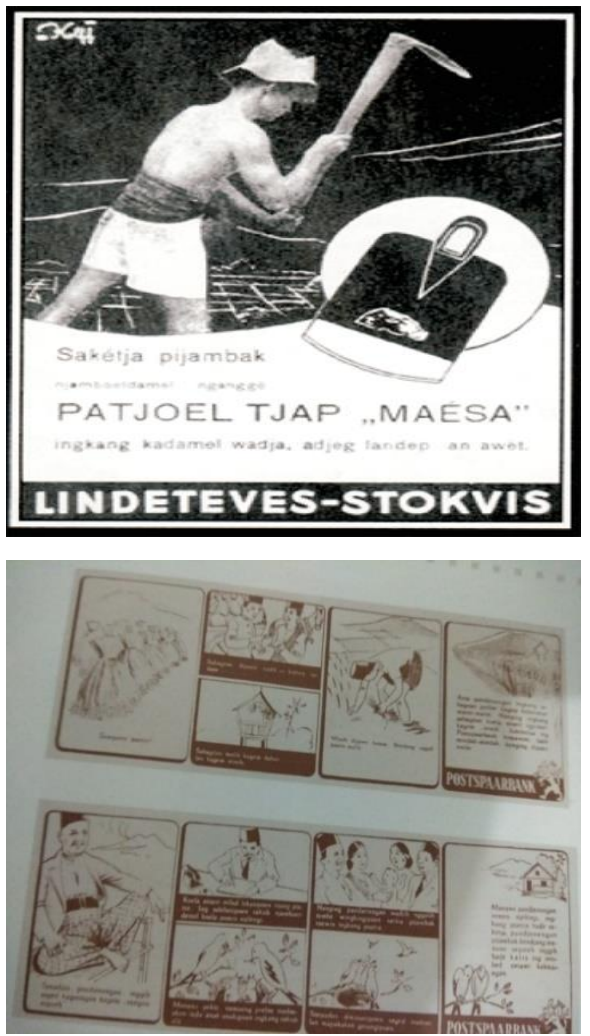

Picture 3. Pacul "Maesa" and Fertilizer Product Advertisements (Source: Kedjawen Magazine)

\subsubsection{Vehicle}
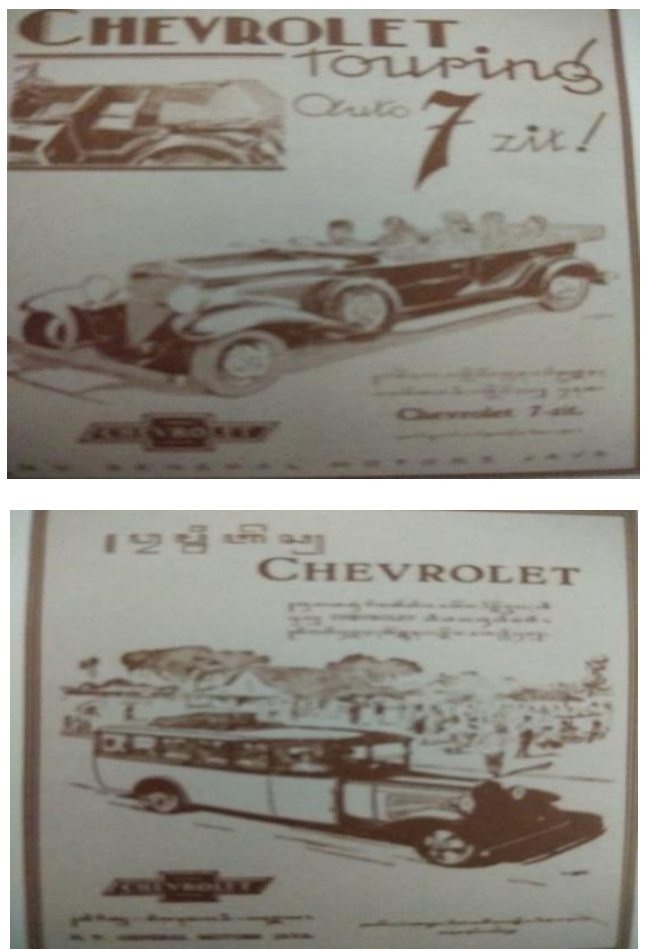

Picture 4. "Chevrolet" car advertisement with Javanese Language and Javanese Alphabet (Source: Kedjawen Magazine)

It is quite interesting if analyzed from several products of goods and services offered in Javanese-language advertisements that contain several values, namely use value, exchange rate, basic use value and additional use value.

In some drug advertisements, there are basic uses such as Quaker Oats food advertisements that have basic use values to overcome malnourished children, but this advertisement was also given additional use values which can make children active in sports activities and can show games good in sports.

Basic use values are also expressed in Colgate toothpaste advertisements, which could make the wearer's teeth whiter, healthier and make breath more fresh and fragrant. Another additional use value is that it can make the wearer have a more charming and attractive smile for anyone who sees it. Some products through advertising try to highlight the use value of a product of goods and services. An example is a vehicle advertisement whether it's a car or bicycle. Hoes and fertilizer products, lamps, shoes and watches products and beauty products such as soap.

Lux bath soap products (Lux scented soap) accentuate the value of the product to make the wearer's body fragrant. Hoe products are used as a product for main use in agricultural activities besides highlighting the strength of the goods (Maesa hoe as a hoe product that is landep (sharp) and durable because it is made of steel 
(ingdipoendamelsakingwadja). for the wearer compared to person who does not use footwear, besides that Bata shoe products also have additional uses, namely "style" in the wearer's fashion so that it looks more elegant, classy and stylish.

Another interesting thing is that the products and services offered are produced or run by foreign companies or based on western culture. For example Bata shoe products, food products such as quaker oats, nestle milk, car products, lighting products and others. The standard of living that was wanted to be offered to the Javanese people at that time was the standard of living of the western people. The advertised standard of living would like to illustrate that foreign products have high quality compared to the standards of goods which are not produced by foreign companies (local products / native products). This is still felt today

\section{CONCLUSIONS AND SugGestions}

\section{A. Conclusion}

The Javanese people on Java Island in the era of 1930 to 1939 had experienced a cultural shift due to the advertisements of products and services offered. At that time there had been a shift or it could be said that there was a clash between eastern culture and western culture and strongly influenced the consumption pattern of Javanese society as part of the Dutch colony.

The Dutch tried to use Javanese people who had a larger number than other people outside Java as a market for products of private foreign companies after the implementation of ethical politics in the Dutch East Indies. In order to "penetrate" the modernization of Javanese society and the success of the commercialization of these products, some advertisements for goods and services use Javanese. It was unavoidable in the 1930s until the end of
1939, most Javanese people, especially the upper middle class, had adopted the values of western culture (nobility, priyayi, intellectuals and politicians).

To more deeply influence the Javanese people's consumptive thinking, some advertisements for a product and service product displayed in several mass media in the form of magazines and one of the Javanese print media used is "Kedjawen" Magazine. The phenomenon of the modernization of advertising of goods and services in Indonesia today is inseparable from the influence of the history of colonialism in Indonesia.

\section{B. Suggestion}

This research requires more approaches (economic, political, social and cultural and even geographical aspects) so it is highly recommended that further follow-up studies be given in mapping the progress of civilization of a society, especially in the Dutch Indies region in the past.

\section{REFERENCES}

[1] Altheide, David L. (1987, Spring). Reflection. Qualitative Sociology,10(1). Human Sciences Press.

[2] Kasuma, Gayung. Makalah: Dari Privacy ke Vulgar: PerilakuSeks di Jawa Awal Abad ke-20. This paper was Presented in the $8^{\text {th }}$ National History Conference, November 2006, Jakarta.

[3] Mrazek, Rudolft. (2006). Engineers of Happy LandPerkembanganTeknologi dan Nasionalisme di SebuahKoloni, Indonesia: Yayasan Pustaka Obor Indonesia.

[5] Rahzen, T., \&Dahlan,M. (2007). Yang Pertama Yang Dibreidel, in Seabad Pers Kebangsaan, Edited by Rahzen\& friends, Jakarta:IBoekoe.

[6] Sachari, Agus. (2007). Budaya Visual Indonesia. Erlangga Jakarta. 